\title{
Soybean yield in response to the industrial seed treatment containing biostimulant fertilizer
}

Pereira, L. C., Matera, T. C., Braccini, A. L., Suzukawa, A. K., Marteli, D. C. V. and Correia, L. V.

\begin{abstract}
SUMMARY
This study aimed at evaluating, during storage, the yield components and germination of the soybean crop based on seeds industrially treated with mineral- biological fertilizer containing amino acids. To achieve this, the experiment was carried out using the completely randomized experimental design with the treatments arranged in subdivided plots, with four replications. The plots included the industrial seed treatments (IST), while the storage periods ( 0 and 45 days) were allocated to the subplots. The following characteristics were assessed: germination, initial stand, number of pods per plant, number of seeds per pods, number of lateral branches per plant, thousand-seed mass and yield. Under the conditions tested, the storage period contributed to a reduction in the agronomic parameters herein assessed, especially considering the control. However, compared to the seeds submitted only to the standard IST and, especially in relation to the untreated seeds (control), the use of biostimulant fertilizer in the industrial treatment enabled an increase in the agronomic characteristics during storage.
\end{abstract}

Key words: Glycine max; productivity; inoculant; nutrients; amino acids.

Pereira, L. C., Matera, T. C., Braccini, A. L., Suzukawa, A. K., Marteli, D. C. V. y Correia, L. V., 2019. Rendimiento de la soja en respuesta al tratamiento industrial con fertilizante bioestimulante de las semillas. Agriscientia 36 (2): 29-37

\section{RESUMEN}

El objetivo del presente trabajo fue evaluar, durante el almacenamiento, los componentes de productividad y la germinación del cultivo de soja, a partir de semillas industrialmente tratadas con fertilizante mineral biológico con aminoácidos. Para ello, se llevó a cabo el experimento empleando un diseño experimental completamente aleatorizado, con tratamientos dispuestos en 
partes subdivididas, de cuatro repeticiones. En las partes fueron incluidos los tratamientos industriales de semillas (TIS), mientras que los períodos de almacenamiento (0 y 45 días) fueron dispuestos en subparcelas. Se evaluaron las siguientes características: germinación, stand inicial, número de vainas por planta, número de semillas por vainas, número de ramificaciones laterales por planta, masa de mil granos y productividad. En las condiciones probadas, el período de almacenamiento contribuyó para la reducción de los parámetros agronómicos evaluados, sobre todo, en comparación con el control. Sin embargo, comparando las semillas sometidas sólo al TIS estándar y, principalmente, con relación a las semillas no tratadas (control), el uso del fertilizante de acción bioestimulante en el tratamiento industrial posibilitó un incremento en las características agronómicas durante el almacenamiento.

Palabras clave: Glycine max; productividad; inoculante; nutrientes; aminoácidos.

Pereira, L. C., Matera, T. C., Braccini, A. L., Suzukawa, A. K., Marteli, D. C. V. y Correia, L. V.: Universidade Estadual de Maringá, Departamento de Agronomia, Av. Colombo, 5790, Maringá -PR, Brasil. Correspondence to: Iucascaiubi@yahoo.com.br

\section{INTRODUCTION}

The use of higher quality seeds plays an important role in the plant stand and, consequently, in the yield of agricultural crops. However, sowing rarely occurs in areas free of phytosanitary threats, which makes the producer opts for the chemical treatment of seeds. In this sense, considering the soybean crop [Glycine max (L.) Merrill], the South American market for seed treatment is projected to reach US\$ 373.87 million by 2020. In Brazil, the largest market of the region, more than $95 \%$ of the sown area makes use of chemically treated seeds (Henning, França Neto, Krzyzanowski and Lorini, 2010), so that $66 \%$ of this total corresponds to the industrial treatment (França-Neto et al., 2015). On the other hand, in Argentina, the second South American country in terms of soybean seed treatment, the demand growth is likely to be at a compounded annual rate of $10.5 \%$ during the 2015-2020 period analysis (Mordor Intelligence, 2017).

Associated with the use of fungicides and insecticides, the application of other products via seeds, such as micronutrients, biostimulants and nitrogen-fixing microorganisms is still widespread in the Brazilian soybean growing system (Embrapa, 2013a). Considering this scenario, to reduce the number of products applied to pre-sowing, the productive sector has sought to provide fertilizers that combine mineral nutrients, nitrogen-fixing microorganisms and biostimulating elements in a single formulation that can be applied to seeds, either by the industry (via IST) or by farmers (on farm treatment).

The literature has plenty of information on the physiological and agronomic performance of soybean seeds treated during pre-sowing with such products (Pereira et al., 2007; Zilli, Campo and Hungria, 2010; Binsfeld, Barbieri, Huth, Cabrera and Henning, 2014). However, unlike the on-farm treatment, the industrial treatment demands prior planning so as to begin preparing the lot from one to two months prior to sowing (Strieder et al., 2014).

In this context, the established hypothesis is that a lot of seeds submitted to different slurries distinctly respond to such mixtures, so that, under field conditions, biostimulant fertilizers might alter the phytotoxic effects of the active ingredients on crop. Therefore, this study aimed at evaluating the yield components and germination performance of the soybean crop during storage, based on seeds industrially treated with mineral- biological fertilizer containing amino acids.

\section{MATERIAL AND METHODS}

The present study was carried out during the 2016-2017 harvest, in an area located at the Experimental Farm of Iguatemi, State University of Maringá (UEM), in Maringá city, North Central region of the State of Parana, located at $23^{\circ} 02^{\prime} \mathrm{S}$, $52^{\circ} 04^{\prime} \mathrm{W}$, with an average altitude of $540 \mathrm{~m}$. The 
predominant type of climate in the region is the Cfa (humid mesothermal, with heavy rainfall and high temperatures in the summer, and dry winters), according to Köppen classification (Caviglione, Kiihl, Caramori and Oliveira, 2000). The experiment was carried out in an area whose cultivation history is based on the succession between soybean or corn in summer and wheat or canola in winter. The soil in the experimental area is classified as Dystroferric Red Argisol with medium texture (Embrapa, 2013b) and its chemical analysis of the $0-20 \mathrm{~cm}$ layer prior to cultivation showed values of $\mathrm{pH}\left(\mathrm{CaCl}_{2}\right)=4.80$, $\mathrm{P}\left(\right.$ Mehlich-1) $=6.18 \mathrm{mg} \mathrm{dm}^{-3}, \mathrm{H}^{+}+\mathrm{Al}^{3+}=4.12 \mathrm{cmol}_{\mathrm{c}}$ $\mathrm{dm}^{-3}, \mathrm{Al}^{3+}=0.10 \mathrm{cmol}_{\mathrm{c}} \mathrm{dm}^{-3}, \mathrm{~K}+=0.41 \mathrm{cmol}_{\mathrm{c}} \mathrm{dm}^{-3}$, $\mathrm{Ca}^{2+}=2.73 \mathrm{cmol}_{\mathrm{c}} \mathrm{dm}^{-3}, \mathrm{Mg}^{2+}=1.35 \mathrm{cmolc} \mathrm{dm}^{-3}$, CTC $=8.61 \mathrm{cmol} \mathrm{dm}^{-3} \mathrm{e} \mathrm{V}=52.13 \%$

Soybean seeds of cultivar NA 5909 RG were used. The seed industrial treatment was carried out in a small-scale industrial unit of the Agronomy Graduate Program of UEM. The treatments consisted in a combination of two storage periods ( 0 and 45 days), with four commercial packages of industrial treatment (Technologies), in which a formulation of a biostimulant biological-mineral fertilizer was added (Table 1). At the end of the treatment, the seeds were packed in kraft paper bags, simulating conventional storage, then the bags were kept in laboratory conditions at $22{ }^{\circ} \mathrm{C}$ and $66 \%$ of relative humidity.

The detailed scheme of the seed industrial treatments employed, with their respective combinations, is shown in Table 1. The fertilizer and commercial packages of industrial treatment (Technologies) were:

Fertilizer: Nutrients (\%): N (4), P (12), K (2.5), $\mathrm{Ca}$ (2.5), S (1.7), B (1.6), Co (0.5), Mo (2.5) and Zn (0.7). Amino acids $\left(D=1.44 \mathrm{~g} \mathrm{~cm}^{-3}\right)$ : methionine,

Table 1. Detailed scheme of the soybean seed industrial treatment with its respective storage periods.

\begin{tabular}{|c|c|c|c|}
\hline Treatments & Description & $\begin{array}{r}\text { Slurry volume } \\
\left(\mathrm{mL} 100 \mathrm{~kg}^{-1}\right)\end{array}$ & $\begin{array}{c}\text { Storage } \\
\text { periods (days) }\end{array}$ \\
\hline$\overline{\mathrm{T} 1}$ & Total control & - & \\
\hline T2 & Technology I & 900 & \\
\hline T3 & $\begin{array}{l}\text { Technology I } \\
\text { + Fertilizer }\end{array}$ & 1100 & \\
\hline T4 & Technology II & 400 & \\
\hline T5 & $\begin{array}{l}\text { Technology II } \\
\text { + Fertilizer }\end{array}$ & 600 & 0 and 45 \\
\hline T6 & Technology III & 750 & \\
\hline T7 & $\begin{array}{l}\text { Technology III } \\
\text { + Fertilizer }\end{array}$ & 950 & \\
\hline T8 & Technology IV & 343,75 & \\
\hline T9 & $\begin{array}{c}\text { Technology IV } \\
+ \text { Fertilizer }\end{array}$ & 543,75 & \\
\hline
\end{tabular}

tryptophan, glutamic acid, alanine, arginine, proline, phenylalanine, lysine, aspartic acid, glycine and valine. Inoculant: Bradyrhizobium spp. $\left(5 \times 10^{9}\right.$ of viable cells $\left.\mathrm{mL}^{-1}\right)$.

Technology I: combination of the carbendazimbased fungicide $150 \mathrm{~g} \mathrm{~L}^{-1}$ + thiram $350 \mathrm{~g} \mathrm{~L}^{-1}$ (Derosal Plus ${ }^{\circledR}$, dose: $200 \mathrm{~mL} 100 \mathrm{~kg}^{-1}$ of seeds), imidacloprid insecticide $150 \mathrm{~g} \mathrm{~L}^{-1}+$ thiodicarb $450 \mathrm{~g} \mathrm{~L}^{-1}$ (Cropstar ${ }^{\circledast}$, dose: $500 \mathrm{~mL} 100 \mathrm{~kg}^{-1}$ of seeds), a polymer (Peridiam 306, dose: $200 \mathrm{~mL} 100 \mathrm{~kg}^{-1}$ of seeds) and a desiccant powder

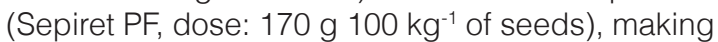
up a slurry volume of $900 \mathrm{~mL} 100 \mathrm{~kg}^{-1}$ of seeds.

Technology II: combination of the fungicide/ insecticide with pyraclostrobin $25 \mathrm{~g} \mathrm{~L}^{-1}+$ methyl thiophanate $225 \mathrm{~g} \mathrm{~L}^{-1}+$ fipronil $250 \mathrm{~g} \mathrm{~L}^{-1}$ (Standak Top ${ }^{\circledR}$, dose: $200 \mathrm{~mL} 100 \mathrm{~kg}^{-1}$ of seeds), a polymer (Florite Green ${ }^{\circledR}, 200 \mathrm{~mL} 100 \mathrm{~kg}^{-1}$ of seeds), and a

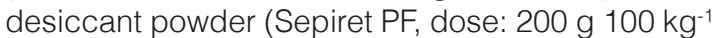
of seeds), making up a slurry volume of $400 \mathrm{~mL}$ $100^{-1}$ of seeds.

Technology III: combination of the fungicide with thiophanate-methyl $350 \mathrm{~g} \mathrm{~L}^{-1}$ + fluazinam

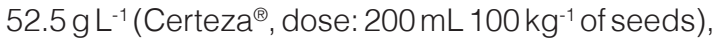
bifenthrin insecticide $135 \mathrm{~g} \mathrm{~L}^{-1}+$ imidacloprid $165 \mathrm{~g} \mathrm{~L}^{-1}$ (Rocks ${ }^{\circledast}$, dose: $350 \mathrm{~mL} 100 \mathrm{~kg}^{-1}$ of seeds),

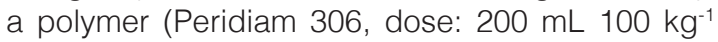
of seeds) and a desiccant powder (Sepiret PF, $200 \mathrm{~g} 100 \mathrm{~kg}^{-1}$ of seeds), making up a slurry volume of $750 \mathrm{~mL} 100 \mathrm{~kg}^{-1}$ of seeds.

Technology IV: combination of the fungicide with metalaxyl-m $10 \mathrm{~g} \mathrm{~L}^{-1}$ + fludioxonil $25 \mathrm{~g} \mathrm{~L}^{-1}$ (Maxim $\mathrm{XL}^{\circledR}$, dose: $62.5 \mathrm{~mL} 100 \mathrm{~kg}^{-1}$ of seeds), thiamethoxam insecticide $350 \mathrm{~g} \mathrm{~L}^{-1}$ (Cruiser 350 $\mathrm{FS}^{\circledR}$, dose: $156.25 \mathrm{~mL} 100 \mathrm{~kg}^{-1}$ of seeds), the

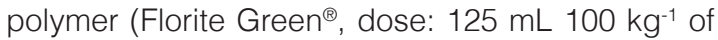
seeds) and a desiccant powder (Sepiret PF, dose: $200 \mathrm{~g} 100 \mathrm{~kg}^{-1}$ of seeds), making up a slurry volume of $343.75 \mathrm{~mL} 100 \mathrm{~kg}^{-1}$ of seeds.

The experiment was carried out using a completely randomized the experimental design, with the treatments arranged in subdivided plots, with four replications. The combinations of the industrial seed treatments were allocated in the plots, and the storage periods ( 0 and 45 days) in the sub-plots. Considering the results of soil analysis, the fertilization was performed mechanically according to Embrapa, (2013a), i. e.: $60 \mathrm{~kg} \mathrm{ha}^{-1}$ triple superphosphate $\left(41 \% \mathrm{P}_{2} \mathrm{O}_{5}\right)$ and $90 \mathrm{~kg} \mathrm{ha}^{-1}$ potassium chloride $\left(60 \% \mathrm{~K}_{2} \mathrm{O}\right)$. Using a density of 28 seeds per linear meter, sowing was mechanically performed under the no-tillage system. The plots consisted of seven lines of $5 \mathrm{~m}$ in length, spaced $0.45 \mathrm{~m}$ apart, using a sowing depth of approximately $3 \mathrm{~cm}$, and a density of 28 
seeds per linear meter. The harvest useful area was constituted by excluding the borders: two external lines, as well as $0.5 \mathrm{~m}$ of each end of the central lines.

The assessed response variables are shown below:

The germination test was conducted with four subsamples of 50 seeds, considering each treatment and analytical repetition. The seeds were placed to germinate among three sheets of germitest paper and moistened with distilled water using the ratio of 2.5 times the weight of the dry substrate. Rolls were prepared, which were taken to germinate in Mangelsdorf type germinator, regulated to maintain a constant temperature of $25 \pm 1^{\circ} \mathrm{C}$. The percentage of normal seedlings was evaluated on the eighth day, after the onset of the test, according to the criteria established in the Rules for Testing Seeds (Ministério da Agricultura, Pecuária e Abastecimento do Brasil, 2009).

The initial plant stand was performed in the useful area of the plots ten days after sowing, the period when the seedlings had already emerged; the results were expressed in number of plants per linear meter. The number of pods per plant, number of seeds per pods and the number of lateral branches per plant were determined in ten plants randomly harvested in the useful area of the plot at the full maturation stage (stage R8).

Both, the yield and thousand-seed mass were determined by harvesting all the plants from the useful area of the experimental units. The plants were manually harvested at crop physiological maturity, which corresponds to the attainment of maximum seed dry weight, also defined as phenological stage R8 (Fehr, Caviness, Burmood and Pennington, 1971). A stationary plotter was used to track the pods and to obtain the seeds, which were duly cleaned and weighed in a scale of one decimal place. The grain moisture and the thousand-seed mass were then determined according to the methodologies described in the Brazilian Rules for Testing Seeds (Ministério da Agricultura, Pecuária e Abastecimento do Brasil, 2009). Then, considering a standard grain moisture of $13 \%$, the results of yield and thousand-seed mass were expressed in $\mathrm{kg} \mathrm{ha}^{-1}$ and in grams, respectively.

The variables that characterized the physiological quality of the seeds, and the yield components were submitted to analysis of variance $(p<0.05)$, using the SISVAR statistical analysis system. Within a same storage period, the means comparison was performed by using Scott-Knott test at $5 \%$ probability. When comparing the storage periods, with only one freedom degree, the $\mathrm{F}$ test was conclusive, at a $5 \%$ probability level (Banzatto and Kronka, 2008).

\section{RESULTS AND DISCUSSION}

Considering all the assessed variables, the seed treatment factor and its interaction with the storage period were significant, at $5 \%$ probability. In general, compared to the untreated control (T1), the variables referred to as germination, number of seeds per pod, number of pods per plant and the thousand-seed mass were beneficially affected by the chemical treatments, regardless of the storage period and the slurry content (Table 2). However, considering the variables initial stand, number of lateral branches and yield, both the control (T1) and the T2 treatment at the initial storage period (zero days) constituted the lowest category, showing an outstanding harmful effect.

Immediately after the processing, except for the control (T1), all the lots were suitable for commercialization, since the average of normal seedlings in the germination test (Table 2) were above the minimum standard of $80 \%$, established by the Ministry of Agriculture, Livestock and Supply as a minimum guarantee for the commercialization of soybean seeds in the country (Ministério da Agricultura, Pecuária e Abastecimento do Brasil, 2013). However, at 45 days of storage (Table 2), only T5 (Technology II + Fertilizer), T6 (Technology III), T7 (Technology III + Fertilizer) and T9 (Technology IV + Fertilizer) treatments did not compromise the physiological quality marketing of the seeds.

In general, the treated seeds showed a percentage of normal seedlings (Table 2) higher than the control (T1). Considering this scenario, however, it is premature to attribute the increases seen in Table 2 purely to the phytonutrient elements of the formulation, since the seeds of medium, such as the lot used in this study, have deteriorated membranes and absorb water faster, in addition to being more susceptible to imbibition damage (Silva and Villela, 2011). Therefore, besides the protective effects of the coating slurries used against seed pathogens, it is likely to consider that the higher germination and initial stand results are also due to the polymers used (liquid and powder-drying ones), which worked as a physical barrier able to reduce the initial speed of water absorption (Evangelista et al., 2007; Kavak and Eser, 2009).

Comparing the treatment pairs of each technology (Table 1), it was seen that the addition of fertilizer to the slurries provided higher results than those observed in the treatments in which such a 
Table 2. Means of the agronomic parameters: germination (G), initial stand (IS), number of lateral branches (NLB), number of seeds per pod (NSP), number of pods per plant (NPP), one thousand-seed mass (TSM) and yield (Yd) of the Nidera 5909 RR cultivar in response to the industrial treatments, with and without fertilizer enriched with amino acids, at zero and at 45 days after treatment.

\begin{tabular}{|c|c|c|c|c|c|c|c|c|}
\hline \multirow{2}{*}{ Treatments } & \multicolumn{2}{|c|}{$\mathrm{G}(\%)$} & \multicolumn{2}{|c|}{ IS (plants $\mathrm{m}^{-1}$ ) } & \multirow{2}{*}{$\begin{array}{c}\text { NLB (unit) } \\
0 \text { days }\end{array}$} & \multicolumn{3}{|c|}{ NSP (unit) } \\
\hline & 0 days & 45 days & 0 days & 45 days & & 45 days & 0 days & 45 days \\
\hline $\mathrm{T1}$ & $77 \mathrm{Ea}$ & $65 \mathrm{~Gb}$ & $14 \mathrm{Ea}$ & $9 \mathrm{Cb}$ & $4.43 \mathrm{Ca}$ & $4.05 \mathrm{~Eb}$ & $2.03 \mathrm{Ca}$ & $1.69 \mathrm{Cb}$ \\
\hline T2 & $81 \mathrm{Da}$ & $69 \mathrm{Fb}$ & $16 \mathrm{Ea}$ & $13 \mathrm{Bb}$ & $4.53 \mathrm{Ca}$ & $4.16 \mathrm{Cb}$ & $2.73 \mathrm{Ba}$ & $2.55 \mathrm{Bb}$ \\
\hline T3 & $88 \mathrm{Ba}$ & $73 \mathrm{~Eb}$ & $19 \mathrm{Da}$ & $15 \mathrm{Ab}$ & 4.70 Aa & 4.38 Bb & $2.91 \mathrm{Aa}$ & $2.66 \mathrm{Ab}$ \\
\hline $\mathrm{T} 4$ & $84 \mathrm{Ca}$ & $78 \mathrm{Db}$ & $16 \mathrm{Da}$ & $11 \mathrm{Bb}$ & $4.65 \mathrm{Ba}$ & $4.25 \mathrm{Cb}$ & $2.82 \mathrm{Ba}$ & $2.57 \mathrm{Bb}$ \\
\hline T5 & $90 \mathrm{Ba}$ & $85 \mathrm{Bb}$ & $25 \mathrm{Ba}$ & $16 \mathrm{Ab}$ & $4.88 \mathrm{Aa}$ & $4.55 \mathrm{Ab}$ & $2.95 \mathrm{Aa}$ & $2.73 \mathrm{Ab}$ \\
\hline T6 & $86 \mathrm{Ca}$ & $80 \mathrm{Cb}$ & $18 \mathrm{Da}$ & $13 \mathrm{Bb}$ & $4.68 \mathrm{Ba}$ & $4.43 \mathrm{Bb}$ & $2.77 \mathrm{Ba}$ & $2.61 \mathrm{Bb}$ \\
\hline $\mathrm{T} 7$ & $95 \mathrm{Aa}$ & $92 \mathrm{Ab}$ & $27 \mathrm{Aa}$ & $17 \mathrm{Ab}$ & $4.93 \mathrm{Aa}$ & $4.58 \mathrm{Ab}$ & $2.98 \mathrm{Aa}$ & $2.77 \mathrm{Ab}$ \\
\hline T8 & $84 \mathrm{Ca}$ & $77 \mathrm{Db}$ & $18 \mathrm{Da}$ & $11 \mathrm{Bb}$ & $4.68 \mathrm{Ba}$ & $4.25 \mathrm{Cb}$ & $2.84 \mathrm{Ba}$ & $2.52 \mathrm{Bb}$ \\
\hline T9 & $89 \mathrm{Ba}$ & $81 \mathrm{Cb}$ & $22 \mathrm{Ca}$ & $15 \mathrm{Ab}$ & $4.85 \mathrm{Aa}$ & $4.40 \mathrm{Bb}$ & $2.93 \mathrm{Aa}$ & $2.68 \mathrm{Ab}$ \\
\hline Mean & 86 & 78 & 20 & 13 & 4.7 & 4.34 & 2.77 & 2.53 \\
\hline CV (\%) & 2.49 & 2.23 & 17.28 & 8.42 & 2.52 & 2.63 & 5.97 & 2.48 \\
\hline \multirow{2}{*}{ Treatments } & \multicolumn{2}{|c|}{ NPP (unit) } & \multicolumn{2}{|c|}{ TSM (grams) } & \multicolumn{2}{|c|}{$\mathrm{Yd}\left(\mathrm{Kg} \mathrm{ha}^{-1}\right)$} & & \\
\hline & 0 days & 45 days & 0 days & 45 days & 0 days & 45 days & & \\
\hline$\overline{\mathrm{T} 1}$ & $38.78 \mathrm{Da}$ & $36.28 \mathrm{Db}$ & $131.10 \mathrm{Fa}$ & 121.30 Fb & $2906 \mathrm{Fa}$ & $1593 \mathrm{Db}$ & & \\
\hline T2 & $40.02 \mathrm{Ca}$ & $37.03 \mathrm{Cb}$ & $137.00 \mathrm{Ea}$ & 128.48 Eb & $3105 \mathrm{Fa}$ & $2169 \mathrm{Cb}$ & & \\
\hline T3 & $41.04 \mathrm{Ba}$ & $38.28 \mathrm{Bb}$ & $149.13 \mathrm{Ba}$ & 134.13 Db & $3748 \mathrm{Da}$ & $2607 \mathrm{Bb}$ & & \\
\hline $\mathrm{T} 4$ & $40.04 \mathrm{Ca}$ & $38.03 \mathrm{Bb}$ & $147.83 \mathrm{Ba}$ & $132.90 \mathrm{Db}$ & 3484 Ea & $2545 \mathrm{Bb}$ & & \\
\hline T5 & $41.29 \mathrm{Ba}$ & $39.04 \mathrm{Bb}$ & $154.53 \mathrm{Ba}$ & $144.55 \mathrm{Bb}$ & $4654 \mathrm{Ba}$ & $3205 \mathrm{Ab}$ & & \\
\hline T6 & $40.04 \mathrm{Ca}$ & $38.03 \mathrm{Bb}$ & 150.15 Ba & $138.30 \mathrm{Cb}$ & $4070 \mathrm{Ca}$ & $2601 \mathrm{Bb}$ & & \\
\hline $\mathrm{T} 7$ & $42.04 \mathrm{Aa}$ & $39.54 \mathrm{Ab}$ & 159.13 Aa & 149.35 Ab & $5888 \mathrm{Aa}$ & $3264 \mathrm{Ab}$ & & \\
\hline T8 & $40.03 \mathrm{Ca}$ & $37.53 \mathrm{Cb}$ & $144.58 \mathrm{Da}$ & 129.95 Eb & $3381 \mathrm{Ea}$ & $2338 \mathrm{Cb}$ & & \\
\hline T9 & $41.29 \mathrm{Ba}$ & $38.65 \mathrm{Bb}$ & $151.53 \mathrm{Ba}$ & $138.83 \mathrm{Cb}$ & $4217 \mathrm{Ca}$ & $2811 \mathrm{Bb}$ & & \\
\hline Mean & 40.51 & 38.05 B & 147.22 & 135.31 & 3940 & 2571 & & \\
\hline CV (\%) & 1.06 & 1.07 & 1.87 & 2.03 & 6.58 & 11.79 & & \\
\hline
\end{tabular}

According to Scott-Knott's grouping criterion, the means followed by the same capital letter in the column belong to the same group at $5 \%$ probability. The means followed by lowercase letters on the same line do not differ among each other, at the $5 \%$ probability level with the $F$ test.

product had not been added. Therefore, it should be highlighted that T5 (Technology II + Fertilizer) and T9 (Technology IV + Fertilizer) were the only treatments that remained commercially available after 45 days of storage, unlike their counterparts T4 (Technology II) and T8 (Technology IV), respectively.

Immediately after the industrial seed treatment (Table 2), the T7 treatment (Technology III + Fertilizer) was the only lot to show a high stand. After storage, however, the stand of lots treated with the fertilizer (T3, T5, T7 and T9) was positively highlighted, whereas the others were grouped into lower (T1) or intermediate (T2, T4, T6 and T8) categories. Similar behavior can be seen in relation to both the number of seeds per pod and the number of lateral branches: higher values were observed with the addition of the fertilizer (T3, T5, T7 and T9), whereas results ranging from low to intermediate were found in slurries without fertilizer (T1, T2, T4, T6 and T8).
Regarding the number of pods per plant, at time zero there was no difference among the four commercial slurries tested (T2, T4, T6 and T8); on the other hand, at 45 days Technology I (T2) and Technology IV (T8) had lower performance than Technology II (T4) and Technology III (T7). In contrast to the other variables, the untreated seeds (T1) were the treatment that provided the lowest number of pods per plant.

Table 2 shows that according to the commercial standards, in the zero period, this is the yield descending order: T6 (Technology III), followed simultaneously by T4 (Technology II), T8 (Technology IV), and finally T2 (Technology I). With the advancement of the storage period, T6 treatment (Technology III) occupied the first position with T4 (Technology II), whereas T2 (Technology I) and T8 (Technology IV) showed the lowest level of values.

However, higher yields were found only by 
using the fertilizer in the IST. Thus, considering the thousand-seed mass and yield, T7 treatment (Technology III + Fertilizer), followed by the T5 (Technology II + Fertilizer) were the first and second-best choices of slurry, respectively, among all the others tested. During the zero period, whereas T7 (Technology III + Fertilizer) provided a grain yield $30.86 \%$ higher than its counterpart (T6), in T5 treatment (Technology $\mathrm{II}+$ Fertilizer) the increase was of $20.58 \%$, compared to T4 (Technology II) (Table 2). On the other hand, T5 treatment (Technology II + Fertilizer) together with T7 (Technology III + Fertilizer) were the highest yield group at 45 days of storage, with a result of $25.90 \%$ higher than its counterpart.

The soybean grain yield is determined by the average number of plants per area, vegetables per area, grains per vegetable and by the average weight of the grains (Scheeren, Peske, Schuch and Barros, 2010). Therefore, in order to clarify the individual contribution of each technology to the performances seen, Table 3 summarizes the grouping categories of the lots treated with commercial slurries (T2, T4, T6 and T8), according to the criterion of Scott-Knott shown in Table 2.

Table 3 shows that only T6 (Technology III) remained in the upper cluster of means, regardless of either the storage period or the response variable. However, considering only period zero, treatments $\mathrm{T} 6$ and T4 were the only ones simultaneously being classified as higher and equivalent to each other.

The variables (Table 3 ) referred to as number of seeds ( 0 and 45 days), initial stand ( 45 days) and number of pods per plant (0 days) showed that in these periods the commercial slurries were equivalent, which highlights that the constant differences in Table 2 probably occurred after adding the fertilizer. At 45 days of storage (Table 3), unlike the germination, the initial stands of the four technologies were equivalent, showing that, in isolation, this parameter may not be enough to explain the yield differences seen during that period.

In this regard, Scheeren et al. (2010) point out the existence of an inverse relation between the stand and the number of pods. However, although T2 (Technology I) had been classified as lower shortly after treatment, the average number of pods per plant did not show significant differences. Therefore, this genetic trait was little influenced by the treatments, even with the addition of the fertilizer (Table 2).

Regarding the phytoactivity of the slurries, Avelar et al. (2011) as well as Pereira, Oliveira, Rosa and Oliveira (2009) suggest that under commercial conditions, the use of systemic fungicides did not promote significant changes in the physiological processes of the plants. On the other hand, when assessing the effect of applying insecticide on the treatment of soybean seeds, Castro, Bogiani, Silva, Gazola and Rosolem (2008) found that certain active ingredients provided improvement, considering the crop agronomic characteristics. Ford et al. (2010), when observing the effect of imidacloprid in Arabidopsis thaliana, showed that, through the induction of genes involved in the biosynthesis of salicylic acid, the imidacloprid provided tolerance to the plant response against pathogens.

However, corroborating the results by Stevens, Reinke, Coombes, Helliwell and Mo (2007); Dan, Dan, Barroso and Braccini (2010) and Dan, Dan, Albrecht, Ricci and Piccinin (2011), in the present work high-volume slurries containing imidacloprid (Technology III: T6 and T7) had adverse effects on the crop yield components. It should be highlighted, however, that in addition to containing biocidal substances different from those of Technology I, it is reasonable to suggest that the favorable result of Technology III might be due to the lower volume of slurry used in T6 and T7 treatments compared to $\mathrm{T} 2$ and $\mathrm{T} 3$.

Table 3. Summary of the means grouping according to Scott-Knott criterion only of the standard treatments (T2, T4, T6 and T8) for the variables germinations (G), initial stand (IS), number of seeds per pod (NSP), number of lateral branches (NLB), number of pod per plant (NPP), and thousand-seed mass (TSM), depending on the storage periods (zero and 45 day).

\begin{tabular}{|c|c|c|c|c|c|c|}
\hline \multirow{2}{*}{ Group } & \multicolumn{2}{|c|}{ G } & \multicolumn{2}{|c|}{ IS } & \multicolumn{2}{|c|}{ NSP } \\
\hline & 0 days & 45 days & 0 days & 45 days & 0 days & 45 days \\
\hline Higher & $\mathrm{T} 4=\mathrm{T} 6=\mathrm{T} 8$ & T6 & $\mathrm{T} 4=\mathrm{T} 6=\mathrm{T} 8$ & \multirow{2}{*}{$\mathrm{T} 2=\mathrm{T} 4=\mathrm{T} 6=\mathrm{T} 8$} & \multirow{2}{*}{$\mathrm{T} 2=\mathrm{T} 4=\mathrm{T} 6=\mathrm{T} 8$} & \multirow{2}{*}{$\mathrm{T} 2=\mathrm{T} 4=\mathrm{T} 6=\mathrm{T} 8$} \\
\hline Lower & $\mathrm{T} 2$ & $\mathrm{~T} 4=\mathrm{T} 8>\mathrm{T} 2$ & $\mathrm{~T} 2$ & & & \\
\hline \multirow{2}{*}{ Group } & \multicolumn{2}{|c|}{ NLB } & \multicolumn{2}{|c|}{ NPP } & \multicolumn{2}{|c|}{ TSM } \\
\hline & 0 days & 45 days & 0 days & 45 days & 0 days & 45 days \\
\hline Higher & $\mathrm{T} 4=\mathrm{T} 6=\mathrm{T} 8$ & T6 & T2-T1-T6-T8 & $\mathrm{T} 4=\mathrm{T} 6$ & $\mathrm{~T} 4=\mathrm{T} 6$ & T6 \\
\hline Lower & $\mathrm{T} 2$ & $\mathrm{~T} 2=\mathrm{T} 4=\mathrm{T} 8$ & $12=14=10=18$ & $\mathrm{~T} 2=\mathrm{T} 8$ & $\mathrm{~T} 8>\mathrm{T} 2$ & $\mathrm{~T} 4>\mathrm{T} 2=\mathrm{T} 8$ \\
\hline
\end{tabular}

= statistically equivalent, $>$ statistically higher. 
Under this scenario, Baldiga Tonin, Lucca Filho, Baudet Labbe and Rossetto (2014) state that the loss of cellular membrane integrity is hypothetically the first event of the seed deterioration process. Thus, the phytotoxicity of the products used in Technology I, coupled with both, the initial mean seed vigor and the high volume of the slurry, increased the damaging of the membranes, resulting in the lack of control of water and solutes changes between the cells and the external environment, which consequently accelerated seed deterioration during storage (Reedy and Knapp, 1990).

Table 3 also shows that under the conditions tested, Technologies II and III were the most promising ones. However, high yield increases were recorded only with the use of fertilizer (Table 2). Therefore, in order to investigate the effect of the fertilizer on the crop yield components, the treatments with this product (Table 1) were compared with each other, according to the origin technology (T3 x T2, T5 x T4, T7 x T6 and T9 $x$ T8). Thus, a relative weight was attributed to each component, in a percentage scale, dividing the values obtained in the lots with fertilizer by the values of their counterparts, without this product (Table 4).

Regarding the first storage period (Table 4), Technology III used with the addition of fertilizer (T7) was the association that provided the largest increases, except for the variable referred to as thousand-seed mass, for which T5 (Technology II + Fertilizer) was positively highlighted. At 45 days, however, T5 was higher in four yield components (initial stand, number of lateral branches, number of seeds per pod and the thousand-seed mass), whereas T7 was only superior in one (number of pods per plants)
Concerning the use of fertilizers in IST, Bays, Baudet, Henning and Lucca Filho (2007) observed no increase either in germination or seed vigor, whereas Binsfeld et al. (2014) showed higher performance in the physiological quality of soybean seed lots of lower vigor by using a micronutrient complex, containing, among other elements, nitrogen and phosphorus, as the fertilizers used in this study. However, it is not possible to credit these mineral elements with the responsibility for the positive effect on the higher soybean yield seen in such an investigation, since during the emergence, the cotyledons are the main responsible for seedling nutrition (Marcos Filho, 2015).

On the other hand, based on Duke and Collins (1985) and Othman, Lie, Mannetje and Wassink (1991), under field conditions, a greater availability of elements such as phosphorus and potassium in the establishment of the crop may positively influence the nodulation process of the plants, so that the first element, besides acting in the energy transfer in the form of adenosine triphosphate (ATP) to the nodule, it provides increases in the number of root hair, thus promoting more infection sites for the bacteria. In relation to potassium, since it directly affects photosynthesis and the translocation of sugars in the phloem, the authors consider it a relevant nutrient in the biological fixation process of the atmospheric nitrogen, because in its deficiency, the sugar supply to the bacterium is impaired.

Numerous mineral fertilizers marketed in the country, such as the formulation tested herein, may contain additives such as amino acids and organic acids, substances that might somehow provide a phytotoxic effect on the physiological performance of soybean seeds such as those described by Ludwig et al. (2011) and Binsfeld et al. (2014). However, the use of phytostimulant elements differs in their action, according to the species and the

Table 4. Percentage of relative increments for germination (G), initial stand (IS), number of seeds per pod (NSP), number of lateral branches (NLB), number of pods per plant (NPP) and thousand-seed mass (TSM) registered after the addition of the fertilizer to technologies I, II, III and IV, depending on the storage periods.

\begin{tabular}{|c|c|c|c|c|c|c|}
\hline \multirow{2}{*}{ Technologies } & \multicolumn{2}{|c|}{$\mathrm{G}(\%)$} & \multicolumn{2}{|c|}{ IS (\%) } & \multicolumn{2}{|c|}{ NLB (\%) } \\
\hline & 0 days & 45 days & 0 days & 45 days & 0 days & 45 days \\
\hline Technology I (T3 x T2) & 7.9 & 6.1 & 16.6 & 17.4 & 3.6 & 5 \\
\hline Technology II (T5 x T4) & 6.6 & 8.2 & 33.3 & 29.9 & 4.7 & 6.6 \\
\hline Technology III (T7 x T6) & 9.5 & 13 & 34.7 & 21.7 & 5.1 & 3.3 \\
\hline Technology IV (T9 x T8) & 5.1 & 4.9 & 17.7 & 31 & 3.5 & 3.4 \\
\hline \multirow{2}{*}{ Technologies } & \multicolumn{2}{|c|}{ NSP (\%) } & \multicolumn{2}{|c|}{ NPP $(\%)$} & \multicolumn{2}{|c|}{ TSM (\%) } \\
\hline & 0 days & 45 days & 0 days & 45 days & 0 days & 45 days \\
\hline Technology I (T3 x T2) & 6.2 & 4.1 & 2.5 & 3.3 & 8.1 & 4.2 \\
\hline Technology II (T5 x T4) & 4.4 & 5.9 & 3 & 2.6 & 4.3 & 8.1 \\
\hline Technology III (T7 x T6) & 7 & 5.8 & 4.8 & 3.8 & 5.6 & 7.4 \\
\hline Technology IV (T9 x T8) & 3.1 & 6 & 3.1 & 2.9 & 4.6 & 6.4 \\
\hline
\end{tabular}


cultivar (Taiz and Zeiger, 2013), which suggests that the response to a given regulatory depends not only on its chemical structure, but also on how it is recognized by target tissue (Raven, Evert and Eichhorn, 2007).

Therefore, although the effects of the technologies on the crop explain part of the performance seen (Table 2 and Table 3), based on the summary shown in Table 4 , it is seen that the increment in the number of plants per linear meter, obtained after using the fertilizer, was the parameter that contributed the most to the increase in crop grain yield.

\section{CONCLUSION}

The storage period of 45 days provided reduction of the germination, initial plant stand, number of pods per plant, number of seeds per pods, number of lateral branches per plant, thousandseed mass and yield, especially considering the control. However, the use of biostimulant fertilizer in the industrial treatment provided an increase in the agronomic traits during storage, compared to the seeds submitted only to the standard combination of plant protection products.

\section{ACKNOWLEDGEMENTS}

This study was partly financed by the Coordenação de Aperfeiçoamento de Pessoal de Nível Superior (CAPES, Brazil).

\section{REFERENCES}

Avelar, S. A. G., Baudet, L., Peske, S. T., Ludwig, M. P., Rigo, G. A., Crizel, R. L. and de Oliveira, S. (2011). Armazenamento de sementes de soja tratadas com fungicida, inseticida e micronutriente e recobertas com polímeros líquido e em pó. Ciência Rural, 41(10), 1719-1725. Retrieved from: http://www.scielo.br/pdf/ cr/v41n10/a13211cr4818.pdf

Banzatto, D. A. and Kronka, S. N. (2008). Experimentação agrícola 4ed. Jaboticabal, Brasil: FUNEP

Bays, R., Baudet, L., Henning, A. A. and Filho, O. L. (2007). Recobrimento de sementes de soja com micronutrientes, fungicida e polímero. Revista Brasileira de Sementes, 29 (2), 60-67.doi:10.1590/ S0101-31222007000200009

Binsfeld, J. A., Barbieri, A. P., Huth, C., Cabrera, I. C. and Henning, L. M. (2014). Uso de bioativador, bioestimulante e complexo de nutrientes em sementes de soja. Pesquisa Agropecuária Tropical, 44 (1), 88-

\section{4. doi:10.1590/S1983-40632014000100010}

Castro, G. A., Bogiani, J. C., da Silva, M. G., Gazola, E. and Rosolem, C. A. (2008). Tratamento de sementes de soja com inseticidas e um bioestimulante. Pesquisa Agropecuária Brasileira, 43(10), 1311-1318. doi:10.1590/S0100-204X2008001000008

Caviglione, J. H., Kiihl, L. B., Caramori, P. H. and Oliveira, D. (2000). Cartas climáticas do Paraná. (1rd ed.) [CDROM], Londrina, Brasil: IAPAR.

Da Silva, K. R. G. and Villela, F. A. (2011). Pré-hidratação e avaliação do potencial fisiológico de sementes de soja. Revista Brasileira de Sementes, 33(2), 331-345. doi:10.1590/s0101-31222011000200016

Dan, L. G. M., Dan, H. A., Barroso, A. L., Lucca e Braccini, A. (2010). Qualidade fisiológica de sementes de soja tratadas com inseticidas sob efeito do armazenamento. Revista Brasileira de Sementes, 32(2), 131-139. doi:10.1590/S0101$\underline{31222010000200016}$

Dan, L. G. M., Dan, H. A., Braccini, A. L., Albrecht, L. P., Ricci, T. T. e Piccinin, G. G. (2011). Desempenho de sementes de soja tratadas com inseticidas e submetidas a diferentes períodos de armazenamento. Revista Brasileira de Ciências Agrárias, 6 (2), 215-222. doi:10.5039/agraria. $\underline{\text { v6i2a939 }}$

Duke, S. H. and Collins, M. (1985). Role of potassium in legume dinitrogen fixation. In: MUNSON, R. D. (Ed.). Potassium in agriculture. Madison, United States: American Society of Agronomy doi:10.2134/1985. potassium.c19

EMBRAPA (2013 a). Tecnologias de produção de soja - Região Central do Brasil 2014. Retrieved June 26, 2019, from: https://ainfo.cnptia.embrapa.br/digital/ bitstream/item/95489/1/SP-16-online.pdf

EMBRAPA (2013b). Sistema brasileiro de classificação de solos (3rd ed.) Brasília, Brasil: Empresa Brasileira de Pesquisa Agropecuária.

Evangelista, J. E., Oliveira, J. A., Botelho, F. E., Oliveira, R. E., Pereira, C. E. (2007). Desempenho de sementes de soja peliculizadas em solo com diferentes teores de água. Ciência e Agrotecnologia, 31(4), 994-999. doi:10.1590/S1413-70542007000400008

Fehr W. R., Caviness C. E., Burmood D. T. and Pennington J. S. (1971). Stage of development descriptions for soybeans, Glycine max (L.) Merrill. Crop Science, 11 (6), 929-931. doi:10.2135/cropsci1971.0011183X0011 $00060051 x$

Ford, K. A., Casida, J. E., Chandran, D., Gulevich, A. G., Okrent, R. A., Durkin, K. A., Sarpong, R., Bunnelle, E. M. and Wildermuth, M. C. (2010). Neonicotinoid insecticides induce salicylate-associated plant defense responses. Proceedings of the National Academy of Sciences, 107 (41), 17527-17532. 


\section{doi:10.1073/pnas. 1013020107}

França-Neto, J. B., Henning, A. A., Krzyzanowski, F. C., Henning, F. A. and Lorini, I. (2015). Adoção dotratamento industrial de sementes de soja no Brasil, safra 2014/15. In: VII Congresso Brasileiro de Soja -Tecnologia e mercado global: perspectivas para soja. Florianópolis, Brasil: Embrapa Soja. Retrieved June 26, 2019, from: http://www.alice.cnptia.embrapa.br/alice/handle/ doc/1018629

Henning, A. A., França Neto, J. B., Krzyzanowski, F. C. and Lorini, I. (2010). Importância do tratamento de sementes de soja com fungicidas na safra 2010/2011, ano de "La Niña". (Technical Report, 82). Londrina, Brasil: Empresa Brasileira de Pesquisa Agropecuária (EMBRAPA). Retrieved June 26, 2019, from: http:// www.infoteca.cnptia.embrapa.br/infoteca/handle/ doc/866711

Kavak, S. and Eser, B. (2009). Influence of polymer coatings on water up take and germination of onion (Allium cepa L. cv. Aki) seeds before and after storage. Scientia Horticulturae, 121 (1), 7-11. doi:10.1016/i.scienta.2009.01.020

Ludwig, M. P., Filho, O. L., Baudet, L., Dutra, L. C., Avelar, S. G. and Crizel, R. L. (2011). Qualidade de sementes de soja armazenadas após recobrimento com aminoácido, polímero, fungicida e inseticida. Revista Brasileira de Sementes, 33(3), 395-406. doi:10.1590/ S0101-31222011000300002

Marcos-Filho, J. (2015). Fisiologia de sementes de plantas cultivadas. (2nd ed.), Londrina, Brasil: ABRATES

Ministério da Agricultura, Pecuária e Abastecimento do Brasil (2009). Regras para análise de sementes. Brasília, Distrito Federal: Assessoria de Comunicação Social. Retrieved from: http://www.agricultura.gov. br/assuntos/insumos-agropecuarios/arquivospublicacoes-insumos/2946 regras analise sementes.pdf

Ministério da Agricultura, Pecuária e Abastecimento do Brasil (2013). Padrões para a produção e a comercialização de sementes de soja - Instrução Normativa $n^{\circ}$ 45, de 17 de setembro de 2013. Brasília, Brasil: Diário Oficial da República Federativa do Brasil

Mordor Intelligence (2017). South America soybean seed treatment market - Segmented by application and geography - Growth, Trends, and Forecast (2018 - 2023). (Technical Report) Hyderabad, India: Mordor Intelligence.

Othman, W. W., Lie, T. A., Mannetje, L. and Wassink, G. Y. (1991). Low level phosphorus supply affecting nodulation, $\mathrm{N}_{2}$ fixation and growth cowpea (Vigna unguiculata). Plant and Soil, 135(1), 67-74. doi:10.1007/BF00014779

Pereira, C. E., Oliveira, J. A., Evangelista, J. E., Botelho, F. E., Oliveira, G. E. and Trentini, P. (2007). Desempenho de sementes de soja tratadas com fungicidas e peliculizadas durante o armazenamento. Ciência e Agrotecnologia, 31(3), 656-665. doi:10.1590/S1413$\underline{70542007000300009}$

Pereira, C. E., Oliveira, J. A., Rosa, M. M., Oliveira, G. E. and Neto, J. C. (2009). Fungicide treatment of soybean seeds inoculated with Colletotricum truncatum. Ciência Rural, 39 (9), 2390-2395. doi:10.1590/S010384782009005000215

Raven, P. H., Evert, R. F. and Eichhorn, S. E (2007). Biologia vegetal. (7th ed.). Rio de Janeiro, Brasil: Guanabara Koogan.

Reedy, M. E. and Knapp, A. D. (1990). Ethanol evolution during the early germination of artificially aged soybean seeds. Journal of Seed Technology, 14(2), 74-82. Retrieved from: http://www.jstor.org/stable/23432832

Scheeren, B. R., Peske, S. T., Schuch, L. O. B and Barros, A. C. A. (2010). Qualidade fisiológica e produtividade de sementes de soja. Revista Brasileira de Sementes, 32 (3), 35-41. doi:10.1590/S010131222010000300004

Stevens, M. M., Reinke, R. F., Coombes, N. E., Helliwell, S. and Mo, J. (2007). Influence of imidacloprid seed treatments on rice germination and early seedling growth. Pest Management Science, 64(3), 215-222. doi:10.1002/ps.1499

Strieder, G., Foguesatto, R. J., Gadotti, G. I., Luz, M. S., Luz, C. S., Gomes, M. C. and Scherer, V. S. (2014). Estudo técnico e de cenários econômicos para implantação de uma unidade de tratamento industrial de sementes de soja e trigo. Informativo Abrates, 24(1), 118-123.

Taiz, L. and Zeiger, E. (2013). Fisiologia vegetal (5th ed.). Porto Alegre, Brasil: Artmed.

Tonin, R. F. B., Filho, O. A. L., Labbe, L. M. B. and Rossetto, M. (2014). Potencial fisiológico de sementes de milho híbrido tratadas com inseticidas e armazenadas em duas condições de ambiente. Scientia Agropecuaria, 5(1), 7-16. Retrieved from: http://www.scielo.org.pe/scielo.php?script=sci_arttext andpid=S2077-99172014000100001

Zilli, J. E., Campo, R. J. and Hungria, M. (2010). Eficácia da inoculação de Bradyrhizobium em pré-semeadura da soja. Pesquisa Agropecuária Brasileira, 45(3), 335338. doi:10.1590/S0100-204X2010000300015 